\title{
Pengaruh Jenis Teh Kompos dan Mulsa Organik terhadap Pertumbuhan dan Hasil Tanaman Kacang Mungo (Vigna mungo (L.) Hepper) Var. Lokal Timor
}

\author{
Miryam Kamlasi ${ }^{\mathrm{a}}$, Syprianus Ceunfin ${ }^{\mathrm{b}}$, dan Maria Afnita Lelang ${ }^{\mathrm{c}}$ \\ ${ }^{a}$ Fakultas Pertanian, Universitas Timor, Kefamenanu, TTU - NTT, Indonesia. \\ ${ }^{b}$ Fakultas Pertanian, Universitas Timor, Kefamenanu, TTU - NTT, Indonesia. \\ ${ }^{c}$ Fakultas Pertanian, Universitas Timor, Kefamenanu, TTU - NTT, Indonesia.
}

\section{Article Info}

\section{Article history:}

Received in revised form 19 Maret 2018

Accepted 4 April 2018

\section{Keywords:}

Teh Kompos

Mulsa Organik

Kacang Mungo
Received 19 Juli 2017

\begin{abstract}
Abstrak
Kacang mungo ini berasal dari India dan telah dibudidaya dari zaman kuno serta merupakan salah satu kacang yang sangat berharga di India dan Pakistan. Kacang mungo di Nusa Tenggara Timur, khususnya di Kabupaten Timor Tengah Selatan, Kecamatan Amanatun Utara dikenal dengan nama 'fue metan'. Seiring dengan perkembangan zaman hasil produksi fue metan semakin menurun bahkan hampir punah karena hanya segelintir petani yang masih menjaga, menyelamatkan dengan terus membudidayakan jenis kacang ini. Penelitian ini bertujuan untuk mengetahui pengaruh jenis teh kompos dan jenis mulsa terhadap pertumbuhan dan hasil tanaman kacang mungo. Rancangan yang digunakan dalam penelitian ini adalah Rancangan Acak Kelompok faktorial $4 \times 3$ dan diulang 3 kali. Faktor pertama adalah jenis teh kompos terdiri dari empat aras yaitu kontrol, teh kompos daun kerinyu, teh kompos daun gamal, teh kompos daun kerinyu + daun gamal dan faktor kedua adalah jenis mulsa organik terdiri dati tiga aras yaitu kontrol, mulsa organik dari rumput, mulsa organik dari serbuk gergaji. Hasil penelitian menunjukkan bahwa pemberian teh kompos mampu meningkatkan indeks panen sebesar 26-37\% dari kontrol. Pemberian mulsa pada tanah meningkatkan kadar lengas tanah mengindikasikan daya ikat air tanah lebih baik sehingga mampu meningkatkan berat biji per tanaman. (2018 dipublikasikan oleh Savana Cendana.
\end{abstract}

\section{Pendahuluan}

Vigna mungo (L.) Hepper berasal dari India dan telah dibudidaya dari zaman kuno serta merupakan salah satu kacang yang sangat berharga di India dan Pakistan. Di wilayah India khususnya Andhra pesisir dikenal dengan sebutan back gram. Kacang mungo menyebar ke daerah tropis lainnya melalui imigran India. Kacang mungo populer di India karena digunakan dalam pembuatan makanan. Kacang mungo sangat popular karena memiliki nilai gizi yang tinggi, seperti protein $25 \mathrm{~g}$, kalium $983 \mathrm{mg}$, kalsium $138 \mathrm{mg}$, besi 7,75 mg, niasin 1.447 $\mathrm{mg}$, dan tiamin $0,273 \mathrm{mg}$, selain itu kacang mungo juga dimanfaatkan untuk mencegah penyakit diabetes. Menurut Kays, (2011), di Indonesia kacang ini dikenal dengan nama kacang mungo.

Kacang mungo di Nusa Tenggara Timur (NTT) khususnya di Kabupaten Timor Tengah Selatan (TTS), Kecamatan Amanatun Utara dikenal dengan nama 'fue metan'. Fue metan ini biasanya dibudidayakan pada bulan Juni. Fue metan ini ditanam masyarakat Amanatun Utara untuk memenuhi kebutuhan pokok akan gizi pangan. Seiring dengan perkembangan zaman hasil produksi fue metan semakin menurun bahkan hampir punah karena hanya segelintir petani yang masih menjaga, menyelamatkan dengan terus membudidayakan jenis kacang ini. Salah satu penyebab menurunnya produksi fue metan ini adalah petani lebih memilih varietas-varietas hibrid yang memiliki potensi hasil lebih menjanjikan, selain itu berkurangnya bahan organik tanah yang menyebabkan kesuburan tanah semakin rendah, sebagai akibat penggunaan bahan kimia berlebihan sepert pupuk, pestisida serta faktor serangan hama penyakit tanaman. Salah satu cara tepat mengembalikan kesuburan tanah serta sekaligus mengendalikan serangan hama penyakit adalah dengan memberikan kompos teh pada tanaman kacang untuk memenuhi kebutuhan akan hara tanaman.

Teh kompos adalah seduhan ekstrak kompos menggunakan air sebagai bahan pengekstrak (Berek, 2017). Teh kompos merupakan larutan yang di ekstrak dari kompos padat yang dapat dipakai untuk mengembangkan atau meningkatkan pertanian organik karena teh kompos dapat menyediakan unsur hara bagi tanaman serta berfungsi sebagai biokontrol yang dapat mengendalikan hama dan penyakit tanaman. Pant et al., (2012) menyatakan teh kompos yang diberikan pada tanaman dapat meningkatkan substansi humus, hormon tumbuh, enzim dan senyawa-senyawa organik lainnya di dalam tanah. Walaupun memiliki kelebihan teh kompos diberikan pada tanah dan tanaman efeknya akan berbeda-beda tergantung mutu kompos asalnya serta cara pembuatan tehnya, dan tanaman yang akan diberikan teh kompos, cara pemberian serta konsentrasi teh kompos (Bria, 2016). Walaupun kompos teh memiliki berbagai kelebihan namun tetap saja lahan pertanian harus tetap dijaga kelembabannya agar teh yang jatuh ke dalam tanah tidak hilang melalui penguapan, maka perlu penutupan lahan agar tidak kehilangan hara dan air tanah dengan menggunakan mulsa.

Mulsa adalah bahan atau material yang digunakan untuk menutupi permukaan lahan pertanian dengan maksud dan tujuan tertentu yang prinsipnya adalah untuk meningkatkan produksi tanaman. Penggunaan mulsa dapat memberikan keuntungan antara lain menghemat penggunaan air dengan mengurangi laju evaporasi dari permukaan lahan, memperkecil fluktuasi suhu tanah sehingga menguntungkan pertumbuhan akar dan mikroorganisme tanah, memperkecil laju erosi tanah baik akibat tumbukan butir-butir hujan maupun aliran permukaan dan menghambat laju pertumbuhan gulma (Lakitan, 1995) Hasil penelitian Raharjo \& Kefi, (2016) menunjukkan penggunaan mulsa dapat meningkatkan porositas tanah. Selanjutnya dikatakan bahwa penggunaan mulsa alang-alang mampu meningkatkan hasil terung lokal. Penelitian Naikofi \& Neonbeni, (2016) juga menunjukkan penggunaan mulsa alang-alang dengan ketebalan $2 \mathrm{~cm}$ memberikan pertumbuhan dan hasil terbaik pada tanaman selada. Dari uraian ini maka perlu dilakukan penelitian tentang pengaruh jenis kompos teh dan jenis mulsa organik yang tepat terhadap pertumbuhan dan hasil kacang mungo.

\section{Metode}

Penelitian ini dilaksanakan pada bulan Januari sampai Maret tahun 2017 di kebun percobaan Fakultas Pertanian, Universitas Timor, dengan menggunakan Rancangan Acak Kelompok ( RAK) faktorial $4 \times 3$ dan diulang 3 kali. Faktor pertama adalah jenis teh kompos terdiri dari empat aras yaitu kontrol (A0), teh kompos daun kerinyu (A1), teh kompos daun gamal (A2), teh kompos daun kerinyu+daun gamal (A3) dan faktor kedua adalah jenis mulsa organik terdir dati tiga aras yaitu kontrol (B0), mulsa organik dari rumput (B1), dan mulsa

Penelitian diawali dengan pembersihan lahan dari gulma serta vegetasi lainya untuk selanjutnya dilakukan pengolahan. Pengolahan tanah dilakukan dengan menggunakan cangkul, kemudian tanah digemburkan. Lahan yang digunakan dalam penelitian ini seluas $57,82 \mathrm{~m} 2$. Kemudian lahan dibagi dalam tiga blok, setiap blok terdiri dari 12 petak dengan ukuran petak $1 \times 1 \mathrm{~m}$. Penanaman dilakukan serempak pada semua petak pada sore hari, dengan cara ditugal sedalam $2 \mathrm{~cm}$ dengan menggunakan jarak tanam $20 \mathrm{~cm} \times 20 \mathrm{~cm}$. Jumlah benih per lubang adalah 3 biji per lubang tanam, kemudian dijarangkan pada hari ke 12 dengan meninggalkan 1 tanaman saja. Penambahan unsur hara ke tanaman dan tanah menggunakan kompos teh. Kompos teh yang digunakan dalam penelitian ini dibuat sendiri dengan menggunakan bahan-bahan yang mudah didapat. Bahan-bahan yang digunakan adalah hijauan (daun gamal dan daun kirinyu) dan pupuk kandang sapi. Hijauan berupa daun gamal $20 \mathrm{~kg}$, daun kirinyu $20 \mathrm{~kg}$, dedak $15 \mathrm{~kg}$, pupuk kandang sapi $12 \mathrm{~kg}$, EM4 $120 \mathrm{ml}$, molase $90 \mathrm{~g}$, dan air 5 L. Hijauan dicincang sampai halus. Kemudian dedak, hijauan, dan dicampur merata di atas lantai yang kering. Campuran bahan kemudian disiram larutan EM4, dan molase secara perlahan-lahan bertahap sehingga terbentuk adonan. Selanjutnya ditutup dengan karung setinggi $2-3 \mathrm{~cm}$, lalu dibalik setiap dua har sekali. Kompos yang telah matang kemudian diayak lalu disimpan dalam wadah kedap air dan menghindari cahaya matahari langsung, agar kompos tidak kehilangan kelembabannya dan mikroorganisme tetap hidup sebelum digunakan Kompos teh dibuat dengan mengikuti langkah-langkah sebagai berikut: a) Air disiapkan dalam ember sebanyak $10 \mathrm{~L}$, selanjutnya kompos $1 \mathrm{~kg}$ yang telah dibungkus dengan kain kasa dimasukkan ke dalam ember, dan ditambahkan larutan molase $50 \mathrm{ml}$. Campuran tersebut diaduk selama 24 jam menggunakan aerator dengan posisi aerator dibaringkan sehingga air di dalam ember berputar seperti sedang mengaduk teh. b) Setelah 24 jam, kompos teh yang disaring menggunakan saringan air dan siap untuk diaplikasikan pada tanaman.

Kompos teh diberikan pada tanaman sebanyak $150 \mathrm{ml}$ per tanaman pada pag hari sebelum pukul 08.00 pada saat tanaman berumur 14 Hari Setelah Tanam (HST) dan diulangi setiap 7 hari sekali. Panen dilakukan dengan cara polong kacang mungo dipetik pada saat polong menunjukkan masak fisiologi dengan warna polong berwarna cokelat. Parameter yang diamati dalam penelitian ini adalah:

Suhu tanah diukur dengan cara menancapkan termometer suhu tanah pada kedalaman $5 \mathrm{~cm}$ selama 3 menit pada tiga titik untuk setiap petak, pada siang hari pukul 12.00-14.00 WITA dan dicatat suhunya. Pengukuran suhu tanah dilakukan pada saat tanaman berumur 20 HST kemudian dilanjutkan dengan interval 20 hari sekali sampai vegetatif maksimum. Teknik pengukuran suhu dilakukan sesuai petunjuk Budhyastoro et al., (2006).

b. Kadar Lengas Tanah (\%)

Pengukuran kadar lengas tanah dilakukan pada saat tanaman berumur 40 HST dan hanya sekali pengamatan. Sampel tanah diambil dengan cara menggal sedalam $5 \mathrm{~cm}$ pada tiga titik untuk setiap petak. Sampel tanah yang sudah diambil berbentuk gumpalan $\pm 2 \mathrm{~cm}$. Kemudian disimpan dalam wadah plastik yang ditandai dengan label, kemudian ditimbang untuk mengetahui berat basah, selanjutnya dioven selama 48 jam pada suhu $105^{\circ} \mathrm{C}$. Kadar lengas tanah dihitung menggunakan rumus sesuai petunjuk Poerwowidodo, (1993). organik dari serbuk gergaji (B2)

a. $\quad$ Suhu Tanah $\left({ }^{\circ} \mathrm{C}\right)$ 


\section{c. Tinggi Tanaman $(\mathrm{cm})$}

Pengukuran tinggi tanaman diukur dari pangkal batang sampai ujung daun paling tinggi pengukuran menggunakan penggaris sentimeter. Pengukuran dilakukan pada 3 tanaman sampel dalam setiap petak, pengukuran dilakukan pada saat tanaman berumur $20 \mathrm{HST}$, sampai tanaman mencapai pertumbuhan vegetatif maksimum yang ditandai dengan munculnya bunga.

d. Jumlah Tangkai

Jumlah tangkai dihitung semua tangkai yang terbentuk pada 3 tanaman sampel pada setiap petak. Pengukuran dilakukan pada saat tanaman berumur 20 HST, sampai tanaman mencapai pertumbuhan vegetatif maksimum yang ditandai dengan munculnya bunga.

e. Diameter Batang $(\mathrm{mm})$

Pengukuran diameter batang dilakukan dengan menggunakan jangka sorong dengan cara menjepit pada bagian batang $(1 \mathrm{~cm}$ di atas pangkal batang) dari 3 tanaman sampel pada tiap-tiap petak saat tanaman berumur 20 HST, sampai tanaman mencapai pertumbuhan vegetatif maksimum yang ditandai dengan munculnya bunga.

f. Luas Daun $\left(\mathrm{cm}^{2}\right)$

Luas daun diukur saat pertumbuhan vegetatif maksimum yang ditandai dengan munculnya bunga pengukuran dilakukan pada tanaman korban. Daun diukur menggunakan metode imageJ.

g. Panjang Akar

Panjang akar diukur dari pangkal akar hingga ujung akar dengan menggunakan penggaris sentimeter pada 2 tanaman korban dalam setiap petak pengukuran dilakukan pada tanaman korban.

h. Total Bintil Akar

Total bintil akar diukur dengan cara menghitung bintil akar pada 2 tanaman korban yang ada dalam setiap petak

i. Jumlah Bintil Akar Efektif

Bintil akar efektif dilihat dengan cara bintil akar dibelah menggunakan pisau dan akan ditandai dengan cairan berwarna kemerah-merahan dilihat pada tanaman korban

j. Jumlah Bintil Akar Tidak Efektif

Bintil akar efektif dilihat dengan cara bintil akar dibelah menggunakan silet dan akan ditandai dengan cairan berwarna putih dilihat pada tanaman korban.

k. Berat Basah Tanaman

Diukur dengan cara menimbang menggunakan timbangan analitik pada setiap tanaman korban dan pada saat tanaman mencapai pertumbuhan vegetatif maksimum yang ditandai dengan munculnya bunga.

1. Berat Kering Tanaman

Diukur dengan cara tanaman dioven selama 48 jam dengan suhu $75^{\circ} \mathrm{C}$ Kemudian ditimbang menggunakan timbangan analitik.

m. Jumlah Polong Per Tanaman

Dilakukan dengan cara menghitung polong yang terbentuk pada 3 tanaman sampel yang ada dalam setiap petak

n. Jumlah Biji Per Polong

Biji dalam masing-masing polong yang terbentuk dihitung pada 3 tanaman sampel yang ada di dalam setiap petak (setiap kali panen)

o. Berat 100 Biji

Diukur dengan cara mengambil seratus biji dan ditimbang untuk mengetahui beratnya.

p. Berat Biji Per Tanaman

Diukur dengan cara memetik dan membersihkan biji dari polongnya dari tanaman sampel yang ada pada setiap petak kemudian ditimbang untuk mengetahui beratnya.

q. Berat Biji Per Petak

Diukur dengan cara membersihkan biji dari polong tanaman sampel pada setiap petak kemudian ditimbang untuk mengetahui beratnya

r. Indeks Panen (\%)

Indeks panen dihitung dengan cara membandingkan berat bagian tanaman yang bernilai ekonomis dengan berat seluruh bagian tanaman kemudian dikonversi ke satuan \%. Indeks panen dihitung dengan rumus sesuai petunjuk (Yadav et al., 1979)

Data hasil pengamatan kemudian dianalisis dengan menggunakan sidik ragam (Anova) Rancangan Acak Kelompok (RAK) sesuai petunjuk Gomez \& Gomez, (1984). Rata-rata perlakuan selanjutnya diuji lanjut dengan menggunakan Duncan Multiple Range Test (DMRT) dengan tingkat signifikan $5 \%$ menggunakan program SAS 9.1.

\section{Hasil dan Pembahasan}

\subsection{Suhu Tanah}

Suhu tanah selama penelitian dari pengamatan awal hingga pengamatan terakhir berfluktuasi dengan kisaran suhu antara $35-39{ }^{\circ} \mathrm{C}$ Hasil uji sidik ragam (anova) menunjukkan terjadi interaksi antara pemberian teh kompos dan mulsa organik pada pengamatan 20 dan 60 HST. Selanjutnya pada pengamatan $40 \mathrm{HST}$ terjadi interaksi antara perlakuan. Namun Pada waktu pengamatan 60 HST suhu meningkat pada perlakuan teh kompos daun gamal dan mulsa organik dari rumput (Tabel 1.).

\subsection{Kadar Lengas Tanah}

Hasil Analisis sidik ragam (Anova) menunjukkan tidak terjadi interaksi antara perlakuan teh kompos dan mulsa organik pada waktu pengamatan. Mulsa organik memberi pengaruh yang nyata terhadap kadar lengas tanah. Sedangkan teh kompos tidak memberikan pengaruh yang nyata (Tabel 2.).

\begin{tabular}{|c|c|c|c|c|c|}
\hline \multirow{2}{*}{$\begin{array}{c}\text { Waktu } \\
\text { Pengamatan }\end{array}$} & \multirow{2}{*}{ Jenis Kompos } & \multicolumn{3}{|c|}{ Jenis Mulsa } & \multirow{2}{*}{ Rerata } \\
\hline & & B0 (Kontrol) & B1 (Rumput) & B2 (Serbuk) & \\
\hline \multirow{5}{*}{$20 \mathrm{HST}$} & A0 (Kontrol) & 36,70 & 35,12 & 34,47 & $35,43 \mathrm{a}$ \\
\hline & A1 (Kerinyu) & 36,73 & 34,27 & 34,57 & $35,19 \mathrm{a}$ \\
\hline & A2 (Gamal) & 36,59 & 34,00 & 34,70 & $35,10 \mathrm{a}$ \\
\hline & $\mathrm{A} 3(\mathrm{~K}+\mathrm{G})$ & 37,49 & 36,14 & 35,09 & $36,24 \mathrm{a}$ \\
\hline & Rerata & $36,85 \mathrm{a}$ & $34,88 \mathrm{a}$ & $34,68 \mathrm{a}$ & $(-)$ \\
\hline \multirow{5}{*}{$40 \mathrm{HST}$} & A0 (Kontrol) & $37,96 \mathrm{bc}$ & $37,18 \mathrm{c}$ & $38,53 \mathrm{bc}$ & $37,89 \mathrm{~b}$ \\
\hline & A1 (Kerinyu) & $38,57 \mathrm{bc}$ & $37,96 \mathrm{bc}$ & $39,54 a b$ & $38,69 \mathrm{ab}$ \\
\hline & A2 (Gamal) & $40,63 \mathrm{a}$ & $39,27 \mathrm{ab}$ & $37,80 \mathrm{bc}$ & $39,23 \mathrm{a}$ \\
\hline & $\mathrm{A} 3(\mathrm{~K}+\mathrm{G})$ & $37,06 \mathrm{c}$ & $37,93 \mathrm{bc}$ & $38,61 \mathrm{bc}$ & $37,87 \mathrm{~b}$ \\
\hline & Rerata & $38,56 \mathrm{a}$ & 38,08 a & 38,81 a & $(+)$ \\
\hline \multirow{5}{*}{$60 \mathrm{HST}$} & A0 (Kontrol) & 34,82 & 36,50 & 37,48 & $36,27 \mathrm{~b}$ \\
\hline & A1 (Kerinyu) & 38,54 & 39,01 & 38,27 & $38,61 \mathrm{a}$ \\
\hline & A2 (Gamal) & 38,34 & 39,93 & 40,20 & 39,49 a \\
\hline & $\mathrm{A} 3(\mathrm{~K}+\mathrm{G})$ & 37,49 & 36,14 & 35,09 & $36,24 \mathrm{~b}$ \\
\hline & Rerata & $37,55 \mathrm{a}$ & $37,90 \mathrm{a}$ & $37,86 \mathrm{a}$ & $(-)$ \\
\hline
\end{tabular}

Keterangan: Angka pada baris dan kolom yang diikuti dengan huruf yang sama menunjukkan tidak berbeda pada tingkat nyata $(\alpha) 5 \%$ menurut uji DMRT; $(-)$ : Tidak terjadi interaksi antar faktor; $(+)$ : Terjadi interaksi antar faktor.

\section{Tabel 2. Kadar Lengas Tanah (\%)}

\begin{tabular}{ccccc}
\hline \multirow{2}{*}{ Jenis Kompos } & \multicolumn{3}{c}{ Jenis Mulsa } & \multirow{2}{*}{ Rerata } \\
\cline { 2 - 4 } & B0 (Kontrol) & B1 (Rumput) & B2 (Serbuk) & \\
\hline A0 (Kontrol) & 13,20 & 17,27 & 15,77 & $15,41 \mathrm{a}$ \\
A1 (Kerinyu) & 9,40 & 15,50 & 16,00 & $13,63 \mathrm{a}$ \\
A2 (Gamal) & 14,97 & 16,33 & 17,17 & $16,16 \mathrm{a}$ \\
A3 (K+G) & 12,05 & 24,57 & 16,35 & $17,66 \mathrm{a}$ \\
\hline Rerata & $11,80 \mathrm{~b}$ & $18,42 \mathrm{a}$ & $16,26 \mathrm{ab}$ & $(-)$
\end{tabular}

Keterangan: Angka pada baris dan kolom yang diikuti dengan huruf yang sama menunjukkan tidak berbeda pada tingkat nyata $(\alpha) 5 \%$ menurut uji DMRT; $(-)$ : Tidak terjadi interaksi antar faktor.

\subsection{Tinggi Tanaman}

Tanaman terus bertambah tinggi selama penelitian. Hasil analisis sidik ragam (Anova) menunjukkan tidak terjadi interaksi antara perlakuan jenis teh kompos dan jenis mulsa organik pada pengamatan tinggi tanaman 20,27,34, dan 41 HST. pada pengamatan tinggi tanaman 20 dan 27 HST tanpa perlakuan jenis teh kompos dan mulsa organik dari serbuk gergaji menunjukkan pengaruh yang nyata terhadap tinggi tanaman, tetapi pada pengamatan tinggi tanaman 41 HST pemberian teh kompos dari daun kerinyu dan pemberian mulsa organik dari serbuk gergaji memiliki kecenderungan lebih tinggi.

Tabel 3. Tinggi Tanaman $(\mathrm{cm})$

\begin{tabular}{|c|c|c|c|c|c|}
\hline \multirow{2}{*}{$\begin{array}{c}\text { Waktu } \\
\text { Pengamatan }\end{array}$} & \multirow{2}{*}{ Jenis Kompos } & \multicolumn{3}{|c|}{ Jenis Mulsa } & \multirow{2}{*}{ Rerata } \\
\hline & & B0 (Kontrol) & B1 (Rumput) & B2 (Serbuk) & \\
\hline \multirow{5}{*}{$20 \mathrm{HST}$} & A0 (Kontrol) & 7,44 & 8,50 & 10,17 & $8,70 \mathrm{a}$ \\
\hline & A1 (Kerinyu) & 7,67 & 8,70 & 9,17 & $8,51 \mathrm{a}$ \\
\hline & A2 (Gamal) & 6,72 & 8,33 & 9,28 & 8,11 a \\
\hline & $\mathrm{A} 3(\mathrm{~K}+\mathrm{G})$ & 7,54 & 7,72 & 9,50 & $8,26 \mathrm{a}$ \\
\hline & Rerata & $7,41 \mathrm{~b}$ & $8,30 \mathrm{~b}$ & $9,46 \mathrm{a}$ & $(-)$ \\
\hline \multirow{5}{*}{$27 \mathrm{HST}$} & A0 (Kontrol) & 9,87 & 10,17 & 12,51 & $10,85 \mathrm{a}$ \\
\hline & A1 (Kerinyu) & 9,26 & 10,52 & 10,52 & $10,10 \mathrm{a}$ \\
\hline & A2 (Gamal) & 8,56 & 10,62 & 10,51 & $9,90 \mathrm{a}$ \\
\hline & $\mathrm{A} 3(\mathrm{~K}+\mathrm{G})$ & 9,63 & 9,37 & 11,08 & $10,03 \mathrm{a}$ \\
\hline & Rerata & $9,31 \mathrm{~b}$ & $10,17 \mathrm{ab}$ & $11,03 \mathrm{a}$ & $(-)$ \\
\hline \multirow{5}{*}{$34 \mathrm{HST}$} & A0 (Kontrol) & 15,34 & 15,49 & 17,61 & $16,15 \mathrm{a}$ \\
\hline & A1 (Kerinyu) & 14,33 & 14,83 & 14,09 & $14,42 \mathrm{a}$ \\
\hline & A2 (Gamal) & 13,61 & 16,16 & 13,28 & $14,35 \mathrm{a}$ \\
\hline & $\mathrm{A} 3(\mathrm{~K}+\mathrm{G})$ & 14,78 & 13,66 & 15,22 & $14,55 \mathrm{a}$ \\
\hline & Rerata & $14,48 \mathrm{a}$ & $15,03 \mathrm{a}$ & $14,86 \mathrm{a}$ & $(-)$ \\
\hline \multirow{5}{*}{$41 \mathrm{HST}$} & A0 (Kontrol) & 20,92 & 21,72 & 23,39 & $22,01 \mathrm{a}$ \\
\hline & A1 (Kerinyu) & 19,49 & 25,28 & 22,90 & $22,56 \mathrm{a}$ \\
\hline & A2 (Gamal) & 21,72 & 21,84 & 22,94 & $22,17 \mathrm{a}$ \\
\hline & $\mathrm{A} 3(\mathrm{~K}+\mathrm{G})$ & 22,50 & 19,14 & 24,03 & $21,89 \mathrm{a}$ \\
\hline & Rerata & $20,82 \mathrm{a}$ & $22,00 \mathrm{a}$ & $23,23 \mathrm{a}$ & $(-)$ \\
\hline
\end{tabular}
$(-)$ : Tidak terjadi interaksi antar faktor.

\subsection{Jumlah Tangkai}

Jumlah tangkai terus bertambah banyak selama penelitian. Hasil analisis sidik ragam (Anova) menunjukkan tidak terjadi interaksi dan tidak menunjukkan pengaruh yang nyata antara perlakuan jenis teh kompos dan jenis mulsa organik terhadap pengamatan jumlah tangkai 20, 27., 34, dan 41 HST. Namun pada pengamatan 41 HST pemberian teh kompos dari daun gamal dan pemberian mulsa organik dari serbuk gergaji memiliki kecenderungan meningkat (Tabel 4.).

\subsection{Diameter Batang}

Diameter batang terus bertambah besar selama penelitian. Hasil Analisis sidik ragam (Anova) menunjukkan tidak terjadi interaksi antara perlakuan jenis teh kompos dan jenis mulsa organik terhadap pengamatan diameter batang 20,27, 34,dan 41 HST. Pada pengamatan 20 HST tanpa pemberian mulsa organik berbeda nyata dengan pemberian mulsa dari serbuk gergaji dan rumput, tetapi 
pada pengamatan 41 HST dengan tanpa pemberian teh kompos dan pemberian mulsa organik dari serbuk gergaji cenderung lebih tinggi di banding pemberian teh kompos dan tanpa mulsa organik (Tabel 5.).

Tabel 4. Jumlah Tangkai Daun

\begin{tabular}{|c|c|c|c|c|c|}
\hline \multirow{2}{*}{$\begin{array}{c}\text { Waktu } \\
\text { Pengamatan }\end{array}$} & \multirow{2}{*}{ Jenis Kompos } & \multicolumn{3}{|c|}{ Jenis Mulsa } & \multirow{2}{*}{ Rerata } \\
\hline & & B0 (Kontrol) & B1 (Rumput) & B2 (Serbuk) & \\
\hline \multirow{5}{*}{$20 \mathrm{HST}$} & A0 (Kontrol) & 1,11 & 1,44 & 1,22 & $1,26 \mathrm{a}$ \\
\hline & A1 (Kerinyu) & 1,11 & 1,22 & 1,00 & $1,11 \mathrm{a}$ \\
\hline & A2 (Gamal) & 1,33 & 1,00 & 1,00 & $1,11 \mathrm{a}$ \\
\hline & $\mathrm{A} 3(\mathrm{~K}+\mathrm{G})$ & 1,11 & 1,00 & 1,00 & $1,04 \mathrm{a}$ \\
\hline & Rerata & $1,16 \mathrm{a}$ & $1,17 \mathrm{a}$ & $1,04 \mathrm{a}$ & $(-)$ \\
\hline \multirow{5}{*}{$27 \mathrm{HST}$} & A0 (Kontrol) & 2,33 & 2,44 & 2,67 & $2,48 \mathrm{a}$ \\
\hline & A1 (Kerinyu) & 2,11 & 2,67 & 2,11 & $2,30 \mathrm{a}$ \\
\hline & A2 (Gamal) & 2,11 & 2,33 & 2,33 & $2,26 \mathrm{a}$ \\
\hline & $\mathrm{A} 3(\mathrm{~K}+\mathrm{G})$ & 2,00 & 2,00 & 2,44 & $2,15 \mathrm{a}$ \\
\hline & Rerata & $2,13 \mathrm{a}$ & $2,36 \mathrm{a}$ & $2,33 \mathrm{a}$ & $(-)$ \\
\hline \multirow{5}{*}{$34 \mathrm{HST}$} & A0 (Kontrol) & 3,11 & 3,78 & 3,56 & $3,48 \mathrm{a}$ \\
\hline & A1 (Kerinyu) & 2,67 & 3,22 & 4,22 & $3,37 \mathrm{a}$ \\
\hline & A2 (Gamal) & 3,11 & 3,44 & 3,67 & $3,41 \mathrm{a}$ \\
\hline & $\mathrm{A} 3(\mathrm{~K}+\mathrm{G})$ & 2,78 & 2,67 & 3,22 & $2,89 \mathrm{a}$ \\
\hline & Rerata & $2,87 \mathrm{a}$ & $3,28 \mathrm{a}$ & $3,78 \mathrm{a}$ & $(-)$ \\
\hline \multirow{5}{*}{$41 \mathrm{HST}$} & A0 (Kontrol) & 3,78 & 3,67 & 4,56 & $4,00 \mathrm{a}$ \\
\hline & A1 (Kerinyu) & 3,11 & 4,22 & 3,89 & $3,74 \mathrm{a}$ \\
\hline & A2 (Gamal) & 3,56 & 4,56 & 4,11 & $4,07 \mathrm{a}$ \\
\hline & $\mathrm{A} 3(\mathrm{~K}+\mathrm{G})$ & 3,11 & 3,44 & 3,67 & $3,41 \mathrm{a}$ \\
\hline & Rerata & $3,33 \mathrm{a}$ & $3,97 \mathrm{a}$ & $4,02 \mathrm{a}$ & $(-)$ \\
\hline
\end{tabular}
$(-)$ : Tidak terjadi interaksi antar faktor.

Tabel 5. Diameter Batang (mm)

\begin{tabular}{|c|c|c|c|c|c|}
\hline \multirow{2}{*}{$\begin{array}{c}\text { Waktu } \\
\text { Pengamatan }\end{array}$} & \multirow{2}{*}{ Jenis Kompos } & \multicolumn{3}{|c|}{ Jenis Mulsa } & \multirow{2}{*}{ Rerata } \\
\hline & & B0 (Kontrol) & B1 (Rumput) & B2 (Serbuk) & \\
\hline \multirow{5}{*}{$20 \mathrm{HST}$} & A0 (Kontrol) & 0,15 & 0,18 & 0,15 & $0,16 \mathrm{a}$ \\
\hline & A1 (Kerinyu) & 0,18 & 0,15 & 0,14 & $0,16 \mathrm{a}$ \\
\hline & A2 (Gamal) & 0,20 & 0,12 & 0,15 & $0,16 \mathrm{a}$ \\
\hline & $\mathrm{A} 3(\mathrm{~K}+\mathrm{G})$ & 0,18 & 0,13 & 0,14 & $0,15 \mathrm{a}$ \\
\hline & Rerata & $0,18 \mathrm{a}$ & $0,15 \mathrm{~b}$ & $0,15 \mathrm{~b}$ & $(-)$ \\
\hline \multirow{5}{*}{27 HST } & A0 (Kontrol) & 0,24 & 0,28 & 0,27 & $0,27 \mathrm{a}$ \\
\hline & A1 (Kerinyu) & 0,27 & 0,26 & 0,23 & $0,26 \mathrm{a}$ \\
\hline & A2 (Gamal) & 0,25 & 0,23 & 0,23 & $0,24 \mathrm{a}$ \\
\hline & $\mathrm{A} 3(\mathrm{~K}+\mathrm{G})$ & 0,26 & 0,24 & 0,23 & $0,25 \mathrm{a}$ \\
\hline & Rerata & $0,26 \mathrm{a}$ & $0,26 \mathrm{a}$ & $0,24 \mathrm{a}$ & $(-)$ \\
\hline \multirow{5}{*}{$34 \mathrm{HST}$} & A0 (Kontrol) & 0,29 & 0,35 & 0,32 & $0,32 \mathrm{a}$ \\
\hline & A1 (Kerinyu) & 0,30 & 0,32 & 0,29 & $0,30 \mathrm{a}$ \\
\hline & A2 (Gamal) & 0,29 & 0,30 & 0,31 & $0,30 \mathrm{a}$ \\
\hline & $\mathrm{A} 3(\mathrm{~K}+\mathrm{G})$ & 0,30 & 0,32 & 0,30 & $0,31 \mathrm{a}$ \\
\hline & Rerata & $0,29 \mathrm{a}$ & $0,32 \mathrm{a}$ & $0,30 \mathrm{a}$ & $(-)$ \\
\hline \multirow{5}{*}{$41 \mathrm{HST}$} & A0 (Kontrol) & 0,34 & 0,40 & 0,44 & $0,39 \mathrm{a}$ \\
\hline & A1 (Kerinyu) & 0,34 & 0,40 & 0,35 & $0,36 \mathrm{a}$ \\
\hline & A2 (Gamal) & 0,35 & 0,39 & 0,41 & $0,38 \mathrm{a}$ \\
\hline & $\mathrm{A} 3(\mathrm{~K}+\mathrm{G})$ & 0,35 & 0,29 & 0,38 & $0,34 \mathrm{a}$ \\
\hline & Rerata & $0,34 \mathrm{a}$ & $0,37 \mathrm{a}$ & $0,39 \mathrm{a}$ & $(-)$ \\
\hline
\end{tabular}

Keterangan: Angka pada baris dan kolom yang diikuti dengan huruf yang sama menunjukkan tidak berbeda pada tingkat nyata $(\alpha) 5 \%$ menurut uji DMRT; $(-)$ : Tidak terjadi interaksi antar faktor.

\subsection{Panjang Akar, Total Bintil Akar, dan Bintil Akar Besar}

Hasil analisis sidik ragam (anova) menunjukkan tidak terjadi interaksi dan beda nyata pada pengamatan panjang akar, total bintil akar, dan bintil akar besar pemerian teh kompos dari daun kerinyu dan tanpa pemberian mulsa organik cenderung lebih tinggi pada pengamatan panjang akar dibanding kontrol dan pemberian mulsa dari rumput dan serbuk. Sedangkan tanpa pemberian teh kompos dan pemberian mulsa organik dari serbuk gergaji menunjukkan angka tertinggi pada pengamatan total bintil akar dan bintil akar besar.

Tabel 6. Panjang Akar (cm), Total Bintil Akar dan Bintil Akar Besar

\begin{tabular}{clcccc}
\hline \multirow{2}{*}{$\begin{array}{c}\text { Parameter } \\
\text { Pengamatan }\end{array}$} & \multirow{2}{*}{ Jenis Kompos } & \multicolumn{3}{c}{ Jenis Mulsa } & \multirow{2}{*}{ Rerata } \\
\cline { 2 - 5 } Panjang & A0 (Kontrol) & 19,73 & 16,17 & 20,00 & $18,63 \mathrm{a}$ \\
Akar & A1 (Kerinyu) & 29,83 & 23,33 & 29,17 & $27,44 \mathrm{a}$ \\
& A2 (Gamal) & 24,67 & 15,50 & 15,00 & $18,39 \mathrm{a}$ \\
& A3 (K+G) & 11,00 & 17,33 & 19,83 & $16,06 \mathrm{a}$ \\
\cline { 2 - 5 } & Rerata & $23,01 \mathrm{a}$ & $18,08 \mathrm{a}$ & $22,63 \mathrm{a}$ & $(-$ ) \\
\hline \multirow{5}{*}{ Total Bintil } & A0 (Kontrol) & 36,33 & 49,33 & 65,00 & $50,22 \mathrm{a}$ \\
Akar & A1 (Kerinyu) & 37,33 & 55,33 & 54,00 & $48,89 \mathrm{a}$ \\
& A2 (Gamal) & 38,67 & 49,00 & 60,67 & $49,44 \mathrm{a}$ \\
& A3 (K+G) & 39,00 & 39,33 & 55,67 & $44,67 \mathrm{a}$ \\
\hline \multirow{5}{*}{ Bintil Akar } & Rerata & $37,73 \mathrm{a}$ & $48,25 \mathrm{a}$ & $57,87 \mathrm{a}$ & $(-)$ \\
Besar & A0 (Kontrol) & 10,00 & 10,00 & 5,33 & $8,44 \mathrm{a}$ \\
& A2 (Kerinyu) & 5,00 & 6,67 & 6,00 & $5,89 \mathrm{a}$ \\
& A3 (Kamal) & 5,00 & 6,00 & 7,00 & $6,00 \mathrm{a}$ \\
\cline { 2 - 5 } & Rerata & 6,00 & 4,33 & 11,00 & $7,11 \mathrm{a}$ \\
\hline
\end{tabular}

Keterangan: Angka pada baris dan kolom yang diikuti dengan huruf yang sama menunjukkan tidak berbeda pada tingkat nyata $(\alpha) 5 \%$ menurut uji DMRT; $(-)$ : Tidak terjadi interaksi antar faktor.

\subsection{Bintil Akar Kecil, Bintil Akar Efektif dan Tidak Efektif}

Hasil analisis sidik ragam (anova) menunjukkan tidak terjadi interaksi dan beda nyata pada pengamatan bintil akar efektif dan bintil akar tidak efektif, namun pada parameter pengamatan bintil akar kecil, untuk perlakuan mulsa organik dari serbuk gergaji berbeda nyata dengan kontrol dan mulsa organik dari rumput. Pada pengamatan bintil akar efektif dengan tanpa pemberian teh kompos dan mulsa organik dari serbuk gergaji cenderung lebih tinggi dibanding pemberian teh kompos dari kerinyu + gamal dan tanpa mulsa organik.

$\underline{\text { Tabel 7. Bintil Akar Kecil, Bintil Akar Efektif dan Bintil Akar Tidak Efektif }}$

\begin{tabular}{clcccc}
\hline Parameter & \multirow{2}{*}{$\begin{array}{c}\text { Jengamatan } \\
\text { Jenis Kompos }\end{array}$} & \multicolumn{3}{c}{ Jenis Mulsa } & \multirow{2}{*}{ Rerata } \\
\cline { 2 - 5 } Bintil Akar & A0 (Kontrol) & 9,33 & 14,67 & 22,33 & $15,44 \mathrm{a}$ \\
Kecil & A1 (Kerinyu) & 13,67 & 21,00 & 21,00 & $18,56 \mathrm{a}$ \\
& A2 (Gamal) & 12,67 & 18,00 & 27,33 & $19,33 \mathrm{a}$ \\
& A3 (K+G) & 12,67 & 14,67 & 22,67 & $16,67 \mathrm{a}$ \\
\cline { 2 - 5 } & Rerata & $12,40 \mathrm{a}$ & $17,08 \mathrm{ab}$ & $22,87 \mathrm{a}$ & $(-)$ \\
\hline \multirow{5}{*}{ Bintil Akar } & A0 (Kontrol) & 9,00 & 16,67 & 22,33 & $16,00 \mathrm{a}$ \\
Efektif & A1 (Kerinyu) & 6,33 & 16,00 & 15,00 & $12,44 \mathrm{a}$ \\
& A2 (Gamal) & 12,33 & 11,67 & 13,67 & $12,56 \mathrm{a}$ \\
& A3 (K+G) & 6,67 & 11,00 & 7,33 & $8,33 \mathrm{a}$ \\
\hline \multirow{3}{*}{ Bintil Akar } & Rerata & $8,13 \mathrm{a}$ & $13,83 \mathrm{a}$ & $14,67 \mathrm{a}$ & $(-)$ \\
Tidak & A1 (Kontrol) & 8,00 & 8,00 & 15,00 & $10,33 \mathrm{a}$ \\
Efektif & A2 (Gamal) & 12,33 & 11,67 & 12,00 & $12,00 \mathrm{a}$ \\
& A3 (K+G) & 8,67 & 13,33 & 12,67 & $11,56 \mathrm{a}$ \\
& Rerata & 14,00 & 9,33 & 26,33 & $16,56 \mathrm{a}$ \\
\hline
\end{tabular}

Keterangan: Angka pada baris dan kolom yang diikuti dengan huruf yang sama menunjukkan tidak berbeda pada tingkat nyata $(\alpha) 5 \%$ menurut uji DMRT; $(-)$ : Tidak terjadi interaksi antar faktor.

3.8 Luas Daun, Berat Segar Berangkasan dan Berat Kering Berangkasan

Hasil analisis sidik ragam (anova) menunjukkan tidak terjadi interaksi dan beda nyata pada pengamatan luas daun, berat segar berangkasan dan berat kering berangkasan untuk perlakuan jenis teh kompos dan jenis mulsa organik. Namun, pemberian teh kompos dari daun kerinyu + daun gamal dan pemberian mulsa dari serbuk gergaji menunjukkan angka tertinggi pada pengamatan luas daun. Pemberian teh kompos dari daun kerinyu + daun gamal dan pemberian mulsa organik dari rumput menunjukkan angka tertinggi untuk pengamatan berat segar berangkasan. Sedangkan tanpa pemberian teh kompos dan pemberian mulsa organik dari serbuk menunjukkan angka tertinggi pada pengamatan berat kering berangkasan.

Tabel 8. Luas Daun $\left(\mathrm{cm}^{2}\right)$, Berat Segar Berangkasan (g) dan Berat Kering Berangkasan $(\mathrm{g})$

\begin{tabular}{|c|c|c|c|c|c|}
\hline \multirow{2}{*}{$\begin{array}{l}\text { Parameter } \\
\text { Pengamatan }\end{array}$} & \multirow{2}{*}{ Jenis Kompos } & \multicolumn{3}{|c|}{ Jenis Mulsa } & \multirow{2}{*}{ Rerata } \\
\hline & & B0 (Kontrol) & B1 (Rumput) & B2 (Serbuk) & \\
\hline \multirow{5}{*}{ Luas Daun } & A0 (Kontrol) & 3,35 & 5,77 & 4,70 & $4,60 \mathrm{a}$ \\
\hline & A1 (Kerinyu) & 6,53 & 10,67 & 9,26 & $8,82 \mathrm{a}$ \\
\hline & A2 (Gamal) & 3,88 & 4,19 & 8,50 & $5,52 \mathrm{a}$ \\
\hline & $\mathrm{A} 3(\mathrm{~K}+\mathrm{G})$ & 5,93 & 5,97 & 9,15 & $9,68 \mathrm{a}$ \\
\hline & Rerata & $4,92 \mathrm{a}$ & $6,65 \mathrm{a}$ & $7,90 \mathrm{a}$ & $(-)$ \\
\hline \multirow{5}{*}{$\begin{array}{r}\text { Berat Segar } \\
\text { Berangkasan }\end{array}$} & A0 (Kontrol) & 30,16 & 24,54 & 49,97 & $34,89 \mathrm{a}$ \\
\hline & A1 (Kerinyu) & 18,45 & 39,11 & 44,09 & $33,88 \mathrm{a}$ \\
\hline & A2 (Gamal) & 45,02 & 11,69 & 37,04 & $31,25 \mathrm{a}$ \\
\hline & $\mathrm{A} 3(\mathrm{~K}+\mathrm{G})$ & 31,96 & 96,34 & 15,44 & $47,92 \mathrm{a}$ \\
\hline & Rerata & $28,81 \mathrm{a}$ & $42,92 \mathrm{a}$ & $38,13 \mathrm{a}$ & $(-)$ \\
\hline \multirow{5}{*}{$\begin{array}{l}\text { Berat Kering } \\
\text { Berangkasan }\end{array}$} & A0 (Kontrol) & 5,98 & 3,64 & 10,28 & $6,63 a$ \\
\hline & A1 (Kerinyu) & 2,55 & 4,98 & 5,45 & $4,33 \mathrm{a}$ \\
\hline & A2 (Gamal) & 5,63 & 1,51 & 4,21 & $3,78 \mathrm{a}$ \\
\hline & $\mathrm{A} 3(\mathrm{~K}+\mathrm{G})$ & 3,56 & 3,67 & 2,32 & $3,18 \mathrm{a}$ \\
\hline & Rerata & $4,05 \mathrm{a}$ & $3,45 \mathrm{a}$ & $5,54 \mathrm{a}$ & $(-)$ \\
\hline
\end{tabular}

Keterangan: Angka pada baris dan kolom yang diikuti dengan huruf yang sama menunjukkan tidak berbeda pada tingkat nyata $(\alpha) 5 \%$ menurut uji DMRT; $(-)$ : Tidak terjadi interaksi antar faktor.

\subsection{Jumlah Polong Per Tanaman, Jumlah Biji Per Polong dan Berat 100 Biji}

Hasil analisis sidik ragam (anova) menunjukkan tidak terjadi interaksi dan beda nyata pada pengamatan jumlah polong per tanaman, berat 100 biji antara perlakuan teh kompos dan mulsa organik, namun untuk parameter pengamatan jumlah biji per polong, untuk perlakuan tanpa mulsa organik berbeda nyata dengan pemberian mulsa dari rumput dan serbuk. Tetapi pada pengamatan jumlah polong pertanaman dan berat 100 biji untuk perlakuan jenis teh kompos dari daun gamal dan tanpa pemberian mulsa organik menunjukkan angka tertinggi dibanding pemberian mulsa organik dari rumput dan serbuk (Tabel 9.).

\subsection{Berat Biji Per Tanaman, Berat Biji Per Petak dan Indeks Panen}

Hasil analisis sidik ragam (anova) menunjukkan tidak terjadi interaksi dan beda nyata pada pengamatan berat biji per tanaman, berat biji per petak, dan indeks panen antara perlakuan teh kompos dan mulsa organik. pemberian teh kompos dari daun gamal dan pemberian mulsa organik dari serbuk gergaji menunjukkan angka tertinggi untuk pengamatan berat biji pertanaman. Tanpa pemberian teh kompos dan pemberian mulsa organik dari rumput menunjukkan angka tertinggi untuk pengamatan berat biji pertanaman. Sedangkan pemberian teh kompos dari daun kerinyu + daun gamal dan tanpa pemberian mulsa menunjukkan angka tertinggi pada pengamatan indeks panen (Tabel 10.). 
Tabel 9. Jumlah Polong Per Tanaman, Jumlah Biji Per Polong, dan Berat 100 Biji (g).

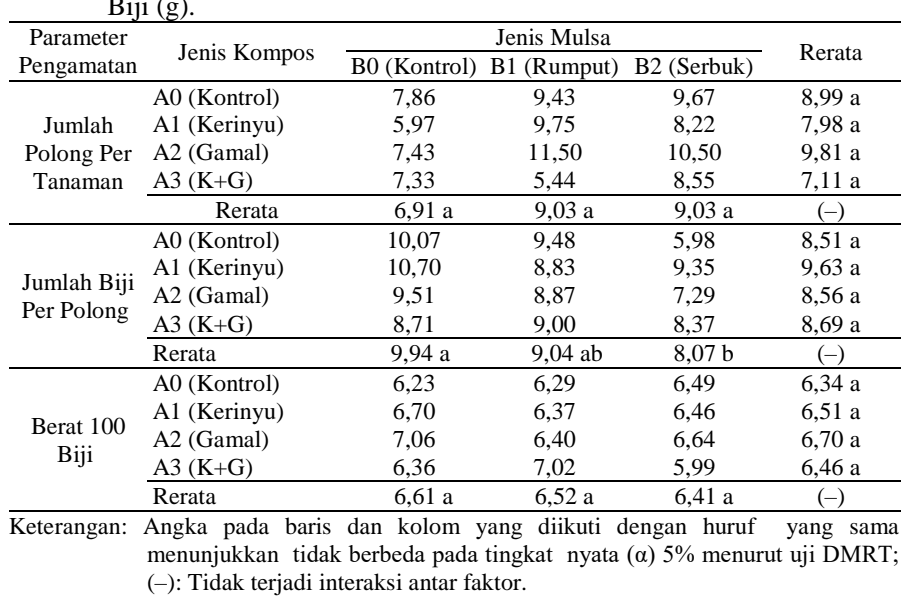

Tabel 10. Berat Biji Per Tanaman (g), Berat Biji Per Petak (t/h) dan Indeks Panen (\%)

\begin{tabular}{|c|c|c|c|c|c|}
\hline \multirow{2}{*}{$\begin{array}{c}\text { Parameter } \\
\text { Pengamatan }\end{array}$} & \multirow{2}{*}{ Jenis Kompos } & \multicolumn{3}{|c|}{ Jenis Mulsa } & \multirow{2}{*}{ Rerata } \\
\hline & & B0 (Kontrol) & B1 (Rumput) & $\overline{\text { B2 (Serbuk) }}$ & \\
\hline \multirow{5}{*}{$\begin{array}{l}\text { Berat Biji } \\
\text { Per } \\
\text { Tanaman }\end{array}$} & A0 (Kontrol) & 20,46 & 16,35 & 18,36 & $18,39 a$ \\
\hline & A1 (Kerinyu) & 15,24 & 20,79 & 18,04 & $18,02 \mathrm{a}$ \\
\hline & A2 (Gamal) & 24,82 & 14,04 & 25,35 & $21,40 \mathrm{a}$ \\
\hline & $\mathrm{A} 3(\mathrm{~K}+\mathrm{G})$ & 15,91 & 21,35 & 16,78 & $18,01 \mathrm{a}$ \\
\hline & Rerata & $18,33 \mathrm{a}$ & $18,13 \mathrm{a}$ & $19,31 \mathrm{a}$ & $(-)$ \\
\hline \multirow{5}{*}{$\begin{array}{l}\text { Berat Biji } \\
\text { Per Petak }\end{array}$} & A0 (Kontrol) & 0,51 & 0,35 & 0,25 & $0,37 \mathrm{a}$ \\
\hline & A1 (Kerinyu) & 0,24 & 0,30 & 0,31 & $0,28 \mathrm{a}$ \\
\hline & A2 (Gamal) & 0,37 & 0,32 & 0,36 & $0,35 \mathrm{a}$ \\
\hline & $\mathrm{A} 3(\mathrm{~K}+\mathrm{G})$ & 0,29 & 0,49 & 0,32 & $0,36 \mathrm{a}$ \\
\hline & Rerata & $0,35 \mathrm{a}$ & $0,36 \mathrm{a}$ & $0,31 \mathrm{a}$ & $(-)$ \\
\hline \multirow{5}{*}{$\begin{array}{l}\text { Indeks } \\
\text { Panen }\end{array}$} & A0 (Kontrol) & 71,61 & 73,26 & 51,75 & $65,54 \mathrm{a}$ \\
\hline & A1 (Kerinyu) & 85,71 & 82,67 & 79,44 & $82,61 \mathrm{a}$ \\
\hline & A2 (Gamal) & 86,65 & 90,12 & 85,47 & $87,42 \mathrm{a}$ \\
\hline & $\mathrm{A} 3(\mathrm{~K}+\mathrm{G})$ & 94,28 & 84,85 & 90,45 & $89,86 \mathrm{a}$ \\
\hline & Rerata & $84,57 \mathrm{a}$ & $82,73 \mathrm{a}$ & $76,78 \mathrm{a}$ & $(-)$ \\
\hline
\end{tabular}

\subsection{Pembahasan}

Parameter pertumbuhan yang diamati terhadap tanaman kacang mungo, menunjukkan perlakuan teh kompos dari daun gamal pertumbuhannya lebih baik dibandingkan dengan kacang mungo yang diberi teh kompos dari daun kerinyu, daun kerinyu + daun gamal dan kontrol. Hal ini disebabkan karena kandungan kimia pada daun gamal mengandung unsur Nitrogen $(\mathrm{N})$.

Menurut Tuti \& Indrawati, (1996) unsur N yang terdapat dalam ekstrak gamal dapat meningkatkan pertumbuhan tinggi tanaman maupun jumlah daun. Pupuk organik cair gamal merupakan pupuk yang memiliki kandungan unsur hara makro dan mikro yang berguna memacu pertumbuhan karena masingmasing unsur yang terkandung di dalamnya memiliki peran tersendiri bagi tanaman dalam proses metabolisme tanaman (Jumini, 2009). Teh kompos juga dapat mengendalikan serangan hama dan penyakit pada tanaman karena di dalam kombinasi teh kompos mengandung mikro organisme yang sifatnya antagonis atau musuh alami terhadap patogen yang menyerang tanaman. Selain sebagai pupuk alami teh kompos juga dapat berfungsi sebagai pestisida alami, karena teh kompos mampu mengembalikan kesuburan tanah secara alami serta meningkatkan daya tahan tanaman terhadap hama dan penyakit (Prihandini \& Purwanto, 2007).

Hasil penelitian menunjukkan bahwa tanaman kacang mungo yang diberi teh kompos dari daun gamal dapat meningkatkan pertumbuhan dan hasil tanaman kacang mungo yang diekspresikan dalam bentuk jumlah tangkai $(4,07)$, bintil akar kecil $(19,33)$, jumlah polong per tanaman $(9,81)$, berat 100 biji $(6,70)$, berat biji per tanaman $(21,40)$.

Mulsa serbuk gergaji lebih baik dibandingkan dengan mulsa rumput untuk menyediakan iklim mikro yang kondusif. Ossom \& Matsenjwa, (2007) menyatakan bahwa mulsa mencegah peningkatan suhu secara ekstrem pada tanah dari pada tanpa pemulsaan.

Hasil penelitian menunjukkan pemberian mulsa organik dari serbuk gergaji terhadap pertumbuhan tanaman kacang mungo menunjukkan hasil terbaik yang diekspresikan dalam bentuk tinggi tanaman $(23,23)$, jumlah tangkai $(4,02)$, diameter batang $(0,39)$, total bintil akar $(5,87)$ bintil akar besar $(7,07)$, bintil akar kecil $(28,87)$, bintil akar efektif $(14,67)$, bintil akar tidak efektif $(15,60)$, luas daun $(7,90)$, berat segar berangkasan $(5,54)$, jumlah polong per tanaman $(9,03)$, berat biji per tanaman $(19,31)$ dibandingkan dengan pemberian mulsa organik dari rumput dan kontrol.

\section{Simpulan}

Tidak terjadi interaksi antara perlakuan jenis teh kompos dan jenis mulsa organik pada semua parameter pengamatan kecuali pada parameter suhu tanah 40 HST. Pemberian teh kompos mampu meningkatkan indeks panen sebesar 26-
$37 \%$ dari kontrol. Pemberian mulsa pada tanah meningkatkan kadar lengas tanah mengindikasikan daya ikat air tanah lebih baik sehingga mampu meningkatkan berat biji per tanaman.

\section{Pustaka}

Berek, A.K. 2017. Teh Kompos dan Pemanfaatannya sebagai Sumber Hara dan Agen Ketahanan Tanaman. Savana Cendana, 2(04): 68-70.

Bria, D. 2016. Pengaruh Jenis dan Konsentrasi Teh Kompos Terhadap Pertumbuhan dan Hasil Bayam Merah (Alternanthera amoena, Voss). Savana Cendana, 1(03): 108-111.

Budhyastoro, T., Tala'ohu, S.H. \& Watung, R.L. 2006. Pengukuran Suhu Tanah. Sifat Fisik Tanah dan Metode Analisisnya. Bogor: Balai Besar Penelitian dan Pengembangan Sumberdaya Lahan Pertanian.

Gomez, K.A. \& Gomez, A.A. 1984. Statistical Procedures for Agricultural Research. New York: John Wiley \& Sons.

Jumini 2009. Pertumbuhan dan Hasil Tanaman Terung Akibat Pemberian Pupuk Daun Gandasil D dan Zat Pengatur Tumbuh Harmonik. Jurnal Floratek, 4(1): 73-80.

Kays, S.J. 2011. Cultivated Vegetables of the World: A Multilingual Onomasticon. Berlin: Springer Science \& Business Media.

Lakitan, B. 1995. Hortikultura I, Teori Budidaya dan Pasca Panen. Jakarta: Raja Grafindo Persada.

Naikofi, K.I.S. \& Neonbeni, E.Y. 2016. Pengaruh Biochar Sekam Padi yang Diperkaya Hara dan Ketebalan Mulsa Terhadap Pertumbuhan dan Hasil Selada Darat (Lactuca sativa, L.). Savana Cendana, 1(04): 116-117.

Ossom, E. \& Matsenjwa, V. 2007. Influence of mulch on agronomic characteristics, soil properties, disease and insect pest infestation of dry bean (Phaseolus vulgaris L.) in Swaziland. World Journal of Agricultural Sciences, 3(6): 696-703.

Pant, A.P., Radovich, T.J., Hue, N.V. \& Paull, R.E. 2012. Biochemical properties of compost tea associated with compost quality and effects on pak choi growth. Scientia horticulturae, 148: 138-146.

Poerwowidodo, M. 1993. Telaah Kesuburan Tanah. Bandung: Angkasa.

Prihandini, P.W. \& Purwanto, T. 2007. Petunjuk Teknis Pembuatan Kompos Kotoran Sapi. Jakarta: Pusat Penelitian dan Pengembangan Peternakan, Badan Penelitian dan Pengembangan Pertanian, Departemen Pertanian.

Raharjo, K.T.P. \& Kefi, T. 2016. Pengaruh Mulsa terhadap Pertumbuhan dan Hasil Kultivar Terung Lokal (Solanum Melongena L.). Savana Cendana, $1(01): 43-46$

Tuti, D. \& Indrawati, I. 1996. Pengaruh dosis pupuk hijau Kirinyuh terhadap ketersediaan $P$ dan hasil cabe (Capsicuum annumm). Tesis. Bandung. Universitas Padjajaran.

Yadav, A., Yadav, T. \& Chaudhary, B. 1979. Path coefficient analysis of the association of physiological traits with grain yield and harvest index in greengram [India]. Indian Journal of Agricultural Sciences, (49): 86-90. 